\title{
PALAEOBOTANY OF THE MESOPHYTIC I PALYNOLOGY OF LOWER TRIASSIC ROGK SALT, HENGELO, THE NETHERLANDS
}

\author{
T. FREUDENTHAL
}

(Botanical Museum and Herbarium, Utrecht)

(received February 27th, 1964)

\begin{abstract}
This paper reports a palynological investigation of Lower Triassic rock salt samples from the eastern part of the Netherlands. Bisaccate pollen grains average $99 \%$ in the spore-pollen complexes. Most important constituent is the group of non-striate pollen grains (about $91 \%$ ), whereas striate pollen grains occur only in a small number (about $8 \%$ ). 19 pollen species are recognized and described, of which 5 are new. Two new genera are described: Eridospollenites and Angustisulcites. The pollen assemblages are compared with Upper Permian and Lower Triassic assemblages from other localities.
\end{abstract}

\section{INTRODUCTION}

In the past ten years many palynological investigations have been carried out of Upper Permian and Lower Triassic sediments. The result was the knowledge of a much greater floral diversity. In northern Europe climatic conditions and the continental sedimentation environment prevailing during Late Permian and Early Triassic were not very suitable for the conservation of plant remains. Oxidized red sandstones and red shales predominate and do not yield an abundance of fossils. However, thick evaporites intercalated between the sandstones and shales have been good media for the preservation of plant remains such as pollen and spores. Most pollen and spores may have been blown in and may have been scattered by wind over extensive areas, in this way being suitable for wide stratigraphic correlations.

Only a few palynological investigations were carried out on Upper Permian and Lower Triassic evaporites, among which the most important are those by Klaus (1953 etc.), PotoniE and Klaus (1954), Leschik (1956), Grebe (1957), DeÁk (1959), Stuhl (1962) and Grebe and SchWEITZER (1962).

The author studied a Lower Triassic (Röt) rock salt formation which has a wide extension in the eastern and northern part of the Netherlands. The samples were taken from the core of drillhole 69 of the Koninklijke Nederlandse Zout Industrie (Royal Dutch Salt Industry).

The investigations were carried out at the Botanical Museum of the State University at Utrecht under direction of Dr. F. P. Jonker, professor of Special Botany. 
The samples and slides are stored at the same museum.

All rock salt samples contained sufficient quantities of pollen and spores to justify a conclusion about their percentages. Generally, the pollen and spores are well preserved and have endured coalification process but to a small degree. The pollen species mentioned below have been recognized in the samples investigated and are described in this paper:

Eridospollenites nov. gen. bentzi (Klaus) nov. comb.

Eridospollenites nov. gen. parous (Klaus) nov. comb.

Jugasporites delasaucei (Potonié and Klaus) Leschik

Jugasporites moersensis Grebe

Klausipollenites schaubergeri (Potonié and Klaus) Jansonius

Falcisporites zapfei (Potonié and Klaus) Leschik

Falcisporites staplini (Jansonius) nov. comb.

Falcisporites triangularis nov. sp.

Falcisporites? grandis nov. sp.

Platysaccus papilionis Potonié and Klaus

Platysaccus hengeloensis nov. sp.

Angustisulcites nov. gen. klausii nov. sp.

Labiisporites granulatus Leschik

Pityosporites devolvens Leschik

Favisporites tenuis Leschik

Taeniaesporites noviaulensis Leschik

Taeniaesporites nubilus (Leschik) nov. comb.

Striatites richteri (Klaus) Jansonius

Protosacculina jansonii nov. sp.

Furthermore, in the assemblages spores average about $1 \%$; most of them may be assigned to the turma Triletes Reinsch. Of most spore species (some may be new) only a few specimens were observed. As they form only a small part of the assemblages and as they do not seem to be very important for stratigraphic purposes in our case, they are not described in this paper.

In three samples Hystrichosphaerideae, assigned to Micrhystridium (Deflandre) Staplin, are observed.

\section{StratigraPhy}

The rock salt formation investigated forms part of the UpperBuntsandstein (Röt). The Buntsandstein represents the lower part of the Triassic.

In the eastern part of the Netherlands the Lower and Middle Buntsandstein are represented by red sandy shales and red sandstones deposited under arid climate conditions and in a continental environment; indications for this are fossilized sun cracks and rain prints.

The transition from Middle to Upper Buntsandstein is marked by a rock salt formation the thickness of which may range between 30 and $60 \mathrm{~m}$. The Upper Buntsandstein becomes more calcareous in its upper part; being a transition from the Lower Triassic continental 
environment to the marine limestones of the Middle Triassic (Muschelkalk).

Up till now no fossils were known from the Lower Triassic deposits

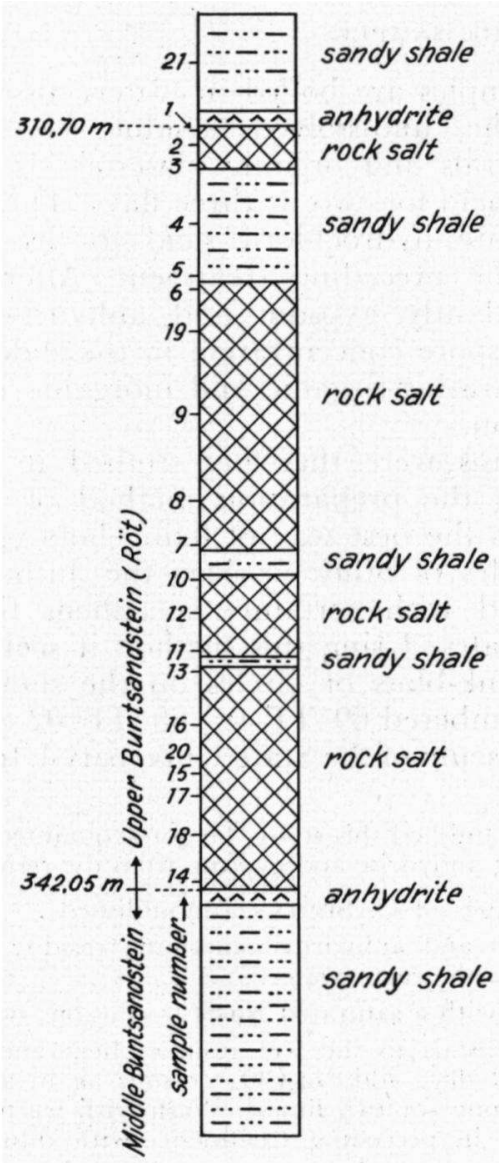

Fig. 1. Section through the Röt rock salt formation, Drillhole 69 of the K. Ned. Zoutindustrie (Hengelo, O.).

in the Netherlands. In the German deposits some outcrops are known to yield plant remains: Pleuromeia, Equisetites, Schizoneura, Albertia, Voltzia, Yuccites. Only the three last-named genera have bisaccate pollen grains. The investigated section is reproduced in Fig. 1. It runs from $310,70 \mathrm{~m}$ to $342,05 \mathrm{~m}$ below the surface; the total thickness amounts to $31,35 \mathrm{~m}$.

Four rock salt beds separated by thin intercalations of sandy or anhydritic shales are present. The bottom and top of the rock salt formation are marked by thin anhydrite beds. In the same Figure the numbers of the samples are indicated. 
This rock salt formation is exploited by the "Koninklijke Nederlandse Zoutindustrie" in the neighbourhood of Hengelo (O) and their production covers the total salt consumption of the Netherlands.

\section{Preparation of the SAMples}

The rock salt samples are boiled in water, dissolving the salt and some gypsum. The undissolved residue-containing anhydrite, gypsum, clay minerals and organic material-is then treated with $45 \%$ hydrofluoric acid for two or three days. Thereupon the residue is boiled with dilute hydrochloric acid to dissolve fluor silicates originating from the preceding treatment. After this the residues still contain abundantly gypsum and anhydrite, which prevents a good pollen and spore concentration in the slides. The author did not succeed in separating organic and inorganic material by means of gravity separation.

Most pollen grains were therefore studied in single-grain slides made according to the preparation method of Erdtman. Making single-grain slides is the best way of fixing holotypes of new species. While studying slides of other workers the author found it mostly impossible to refind with certainty specimens fixed by means of microscope coordinates. Using this method it seems necessary to fix the types also by ink-blots or circles on the slides.

The slides are numbered 69-TF-01, 69-TF-02 etc; they are stored in the Botanical Museum of the State University Utrecht, Netherlands.

After the author had finished this study, he got acquainted with the preparation techniques for removing anhydrite and gypsum from the residue mentioned below:

1. Preparation techniques of C. Sitrler (unpublished).

a. Boil the gypsum and anhydrite containing residue in a saturated $\mathrm{NaCl}$ solution; wash with warm water.

b. Boil the residue with a saturated $\mathrm{Na}_{2} \mathrm{SO}_{4}$ solution; wash with warm water.

c. Add $\mathrm{Na}_{2} \mathrm{CO}_{3}$ crystals to the wet residue, heat and evaporate until the residue is almost dry; add $\mathrm{Na}_{2} \mathrm{CO}_{3}$ crystals again and evaporate (repeat same treatment once or two times). Wash with warm water and treat the $\mathrm{CaCO}_{3}$ (formed in preceding treatment) with dilute hydrochloric acid.

2. Preparation technique of M. H. DEÁK (1959) for dissolving gypsum or gypsum containing shale.

a. Boil the crushed sample with $50 \% \mathrm{KOH}$, meanwhile stirring to prevent clustering of finely dispersed gypsum.

b. Let the undissolved residue settle and suck off the mother lye with a pipette; add water and suck off mother lye again. Repeat this treatment until $\mathrm{KOH}$ is almost washed out.

c. Add concentrated $\mathrm{HCl}$ solution to neutralize $\mathrm{KOH}$ and to dissolve the white precipitate and the constituents dissolvable in $\mathrm{HCl}$.

d. Wash with water and centrifuge.

c. In order to separate inorganic and organic constituents of the remaining residue a centrifuge tube is filled to $3 / 4$ with $\mathrm{ZnCl}_{2}$ solution (specific weight $2,0-2,2)$ and the residue is added.

Centrifuge and suck off the upper part of the liquid containing organic material with a pipette. 
Accidentally the author discovered a new method for bleaching pollen grains. Very dark pollen grains or specimens with heavily thickened bladder bases only showed after a treatment with Shell immersion oil the morphologic features more clearly. This treatment has been made of some specimens of Falcisporites zapfei, Platysaccus papilionis and Taeniaesporites nubilus. The bleaching action of this immersion oil-containing chiefly hydrocarbons together with chlorinated organic compounds-is, though certainly chemical, still unclear to the author. It appeared, however, to be very useful.

\section{Method OF DESGRIPTION}

JANsonius (1962) was the first to give a good method of describing of bisaccate pollen grains. In this paper his method is applied. Fig. 2 (after Jansonius) shows the features to be measured. In most of our

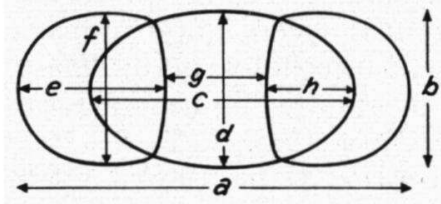

Fig. 2. Measurements in bisaccate pollen grains. overall: $\mathbf{a} \times \mathbf{b}$ central body (c.b.): $c \times d$ bladder: $\mathrm{e} \times \mathbf{f}$ distance between the distal bladder bases (b.b.): $\mathbf{g}$ intramarginal overlap: $\mathrm{h} / \mathrm{e} \times 100 \%$

cases measurements are given according to this scheme in order to facilitate comparison with the Canadian pollen species described by Jansonius. If a few specimens of a species are found only measurements of a figured specimen or holotype are given. Photomicrographs were made on Agepan film with a Leitz Ortholux-Orthomat combination.

\section{Descriptions of THE BISACCATE POLlen SPECIES}

Turma Saccites Erdtman 1947

SubTuRma Disaccites Cookson 1947

INFRATURMA Disaccitriletes Leschik 1955

Type species:

\section{ERIDOSPOLLENTTES novum genus}

Illinites paxerus Klaus, 1963, Jb. Geol. B.-A., 106: 271, t 5. f 18.

Derivatio nominis:

the goddess Eris, who caused confusion about the relationship of many species assigned to Illinites.

Synonym:

Illinites Klaus, 1955, 1963

Illinites Leschik 1956

Illinites Schaarschmidt 1963

Illinites Grebe 1957

Illinites Grebe \& Schweitzer 1962 (partim) 
Description: Bisaccate pollen grains with a trilete $\mathrm{Y}$-mark in the intexine of the central body. The rays of the Y-mark are equal or different in length. Around the Y-mark the exoexine may be present or absent.

The bladders are displaced in the direction of the distal pole. A equatorial connection between the bladders may be present, but it is generally absent.

The shape of the bladders ranges from over semi-circular to crescentshaped; generally the central body is round or rounded oval, but in some specimens it may be oval by squashing.

Discussion: This genus differs from Illinites Kosanke 1950 in its Y-mark. Eridospollenites is characterized by a trilete Y-mark in the intexine of the central body, Illinites is characterized by a trilete Y-mark or irregular rent in the exoexine.

Furthermore, a circular circum-equatorial furrow around the $\mathrm{Y}$-mark or irregular rent is a very important feature of Illinites, which feature is also present in the holotype of Illinites (I. unicus Kosanke).

This feature is visible in the figures of Complexisporites polymorphus Jizba (Jizba, 1962, t 21. f 4, 5, 7, 8).

Illinites (= Complexisporites Jizba 1962, = Kosankeisporites Bhardwaj 1955) is restricted to the Upper Carboniferous and Lower Permian and perhaps it may be regarded as ancestor of the striate pollen. However, Eridospollenites do not have any phylogenetic relationship with striate pollen; probably there is a phylogenetic relationship between Eridospollenites and Jugasporites Leschik 1956.

Eridospollenites bentzi (Klaus) nov. comb.

Plate 1, fig. 1 .

Holotype:

cf. Illinites bentzi Klaus, 1955, Zschr. Deu. Geol. Ges., 105: 780, t 34. f 6.

Synonym:

Illinites bentzi Klaus, 1963, Jb. Geol. B.-A., 106: 274, textf. 16.

Illinites spectabilis Leschik, 1956, Palaeontographica, B, 100: $131, \mathrm{t} 21$, f 5 .

Ilinites unicus Leschik, 1956, Palaeontographica, B, 100: 131, t 21, f 5 .

Remarks: $E$. bentzi is a fairly rare species in the Hengelo assemblages. Most specimens have a slightly greater distance between the bladder bases $(18-28 \mu)$ than the holotype.

The earliest description of $E$. bentzi by KLaus (1953c, p. 55) was not in accordance with the International Code of Botanical Nomenclature (art. 34, 38) and was consequently not valid. KLAUS (1963) validated this species and assigned a holotype, figured -by ; KLAUS $^{-}$ (1955b) as cf. I. bentzi.

I. spectabilis Leschik is characterized by a slightly greater distance between the bladder bases, which is a common feature of the specimens in the Hengelo assemblages.

Occurrence: Upper Permian: Germany, Hungary.

Lower Triassic: Austria, Netherlands. 
Eridospollenites parvus (Klaus) nov. comb.

Plate 1, figs. 2, 3.

Holotype:

Illinites parvus Klaus, 1963, Jb. Geol. B.-A., 106: 271, t 5. f 18.

Synonym:

Illinites of. unicus Kosanke; Grebe, 1957, Geol. Jb., 73: 57, t 6. f 24-26

Illinites gamsi Klaus, 1963, Jb. Geol. B.-A., 106: 273, t 5. f 16.

Description:

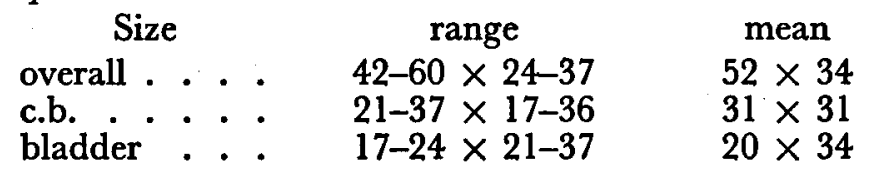

Overall outline elongated oval. Central body yellow-light brown, round, sometimes oval by squashing, with a thin, smooth exine (less than $1 \mu$ ). Central body provided with a distinct trilete Y-mark; ray lengthes range between 2 and $7 \mu$. Mostly one ray is shorter than the other two.

Semi-circular bladders indistinctly attached to central body. Bladder bases unthickened. Bladder reticulum very fine; mesh width less than $1 \mu$.

The bladders may be equatorially connected by a narrow exoexinal strip resembling monosaccate pollen species. Bladders are mostly somewhat lighter coloured than central body.

Discussion: $E$. parous differs from $E$. bentzi in its unthickened bladder bases and smaller dimensions. I. gamsi Klaus is considered a squashed specimen of the species $E$. parous.

Occurrence: Upper Permian: Germany, N. Italy Lower Triassic: Netherlands

\section{JUGASPORITES Leschik 1956}

Type species:

Pityosporites delasaucei Potonié \& Klaus, 1954, Geol. Jb., 68: 538, t 10. f 9.

LESCHIK (1956) mentions as generic type a specimen figured by himself ( $t 24$. f 9 ) instead of the holotype of $P$. delasaucei figured by Potonié and Klaus. From this Potonie (1958, p. 58) draws the conclusion of the unvalidity of the generic name Fugasporites.

However, the diagnosis of Jugasporites is in accordance with the original description of $P$. delasaucei and the redescription of it by Klaus (1955, p. 536). Consequently, Potonié's conclusion is wrong (see also Leschik, 1959, p. 67).

Potonit (1958) and SchaARschmidt (1963) considered Jugasporites a synonym of Limitisporites Leschik 1956; Schaarschmidt assigned the type species of Jugasporites (J. delasaucei) as type species of Limitisporites. 
This procedure is incomprehensible. Limitisporites is characterized by $L$. rectus Leschik; consequently $\mathcal{F}$. delasaucei can never be the type species of Limitisporites.

If $\mathcal{F}$. delasaucei and $L$. rectus are identical $L$. rectus has to be rejected as it has been described later than $\mathcal{F}$. delasaucei ( $\mathcal{~}$. delasaucei Leschik, 1956, p. 132 and $L$. rectus, Leschik, 1956, p. 133).

For the same reasons Limitisporites has to be considered a synonym of Jugasporites.

In the holotype of $L$. rectus the rent is distinctly and sharply bent under the thickened bladder bases, but this feature is invisible in the figure of the holotype.

The specimens assigned by KLAUs (1963) to Limitisporites show a slightly bent laesura; for this reason one had better assign them to Fugasporites. GreBe and SchweItzer (1962) considered Fugasporites and Limitisporites synonyms of Illinites Kosanke. However, there is not any relationship of these two genera with Illinites (see description of Eridospollenites).

Probably there are relationships between Jugasporites and Eridospollenites, but the differences are great enough to justify generic separation. Eridospollenites is characterized by a trilete Y-mark in the intexine, Jugasporites is characterized by a roof-shaped or slightly bent laesura in the intexine; the laesura is not straight!

Jugasporites delasaucei (Potonié and Klaus) Leschik plate 1 , figs. $5,6,7$.

Holotype:

Pityosporites delasaucei Potonié \& Klaus, 1954, Geol. Jb., E8: 538, t 10. f 9. Synonym:

Fugasporites delasaucei (Potonié \& Klaus) Leschik, 1956, Palaeontographica, B, 100: 132, t 21. f 9-11; Grebe, 1957, Geol. Jb., 73: 58, t 6, f 28, 29; Klaus, 1963, Jb. Geol. B.-A., 106: 267, t 6. f 19.

Limitisporites rectus Leschik, 1956, Palaeontographica, B, 100: 133, t 21. f 15; Leschik, 1959, Senck. Leth., 40: 67, t 4, f 30 .

The size of the holotype (longest axis $80 \mu$ ) corresponds with the average size of our specimens. Most important difference with our material is the dark colour of the central body of the holotype.

\begin{tabular}{ccc}
\multicolumn{1}{c}{ Size } & range & mean \\
overall . . . . & $66-100 \times 36-52$ & $81 \times 46$ \\
c.b. . . . . . & $28-36 \times 35-40$ & $32 \times 37$ \\
bladder . . . & $24-36 \times 36-50$ & $33 \times 45$ \\
b.b. . . . . . & $18-25$ & 21
\end{tabular}

According to Potonié and Klaus (1955, pp. 536, 539) this species differs from Falcisporites zapfei (Potonié and Klaus) Leschik in its fine bladder reticulum. This difference can be observed in the Hengelo assemblages.

KLAUS (1955b, p. 780) states: $F$. zapfei differs from $\mathcal{F}$. delasaucei in 
T. FREUDENTHAL: Palaeobotany of the Mesophytic $I$
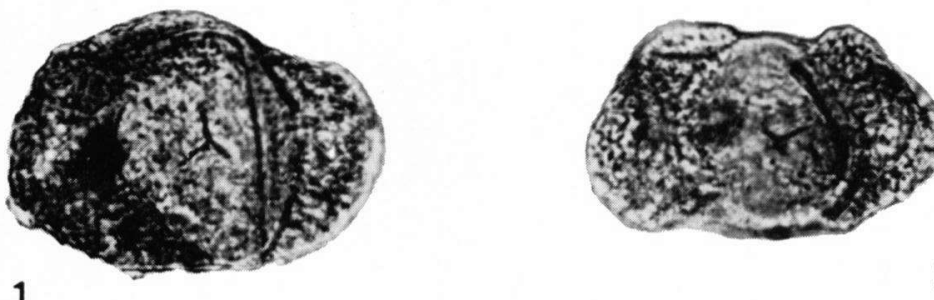

2

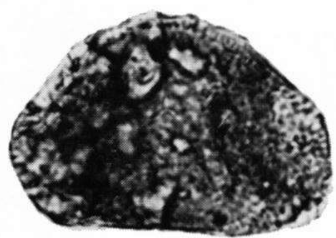

3
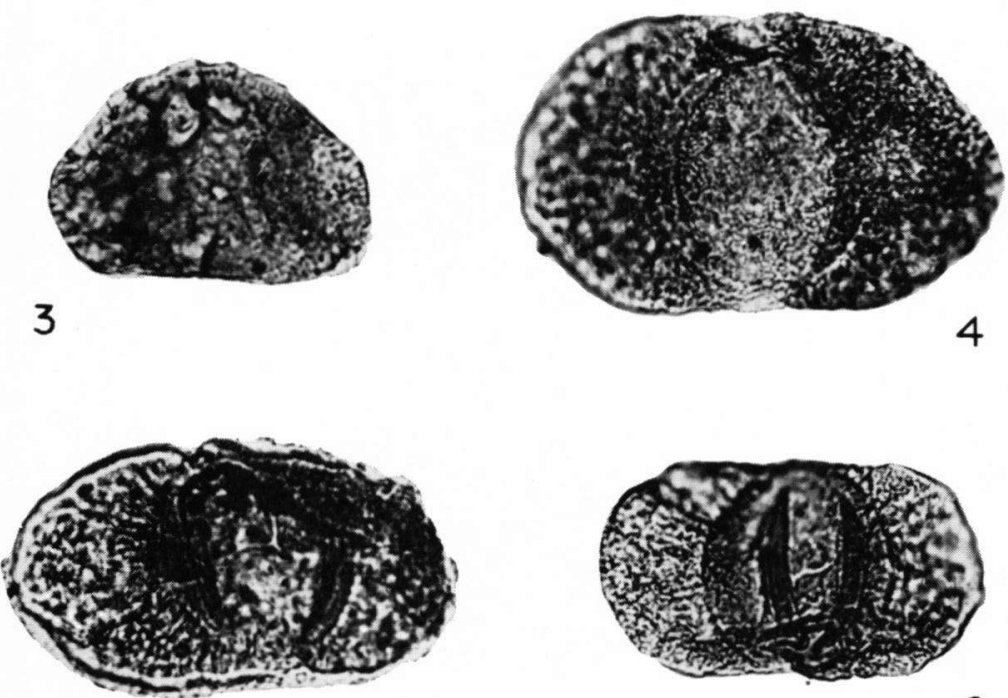

5

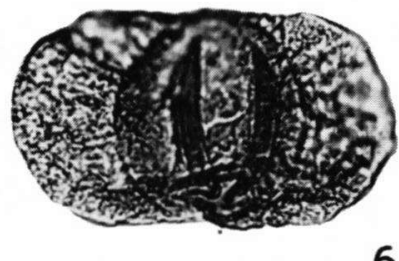

6
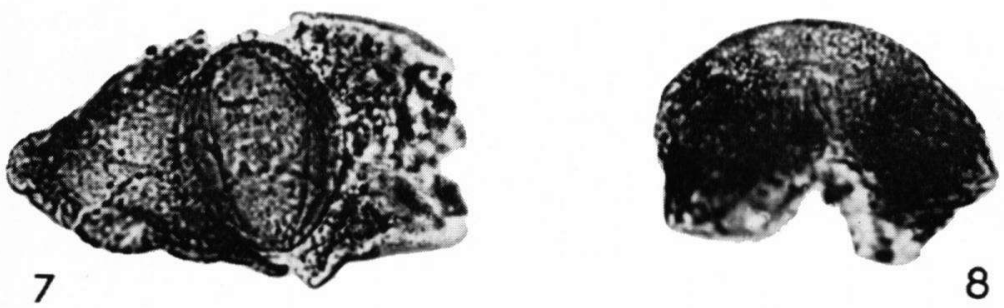

Plate 1. all specimens $600 \times 1$. Eridospollenites bentzi (69-TF-109); 2. Eridospollenites parvus (69-TF-14) ; 3. id. (69-TF-08); 4. Jugasporites moersensis (69-TF-49); 5. Jugasporites delasaucei $(69-\mathrm{TF}-42)$; 6. id. $(69-\mathrm{TF}-44) ; 7$. id. $(69-\mathrm{TF}-43)$; 8. Klausipollenites schaubergeri (69-TF-54). 

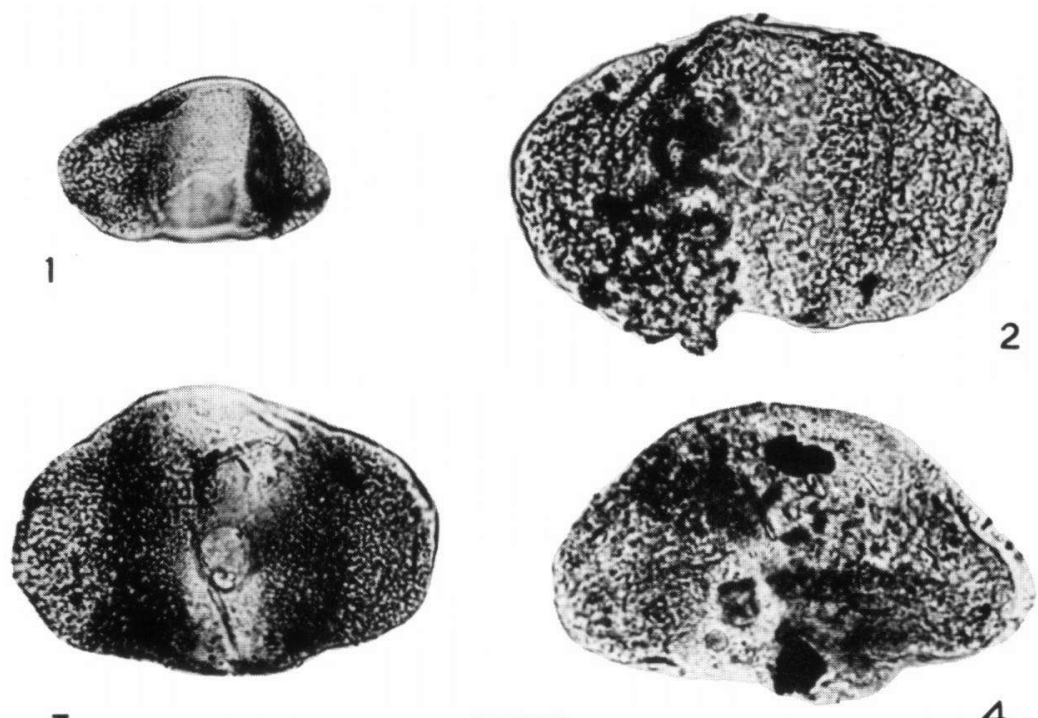

3

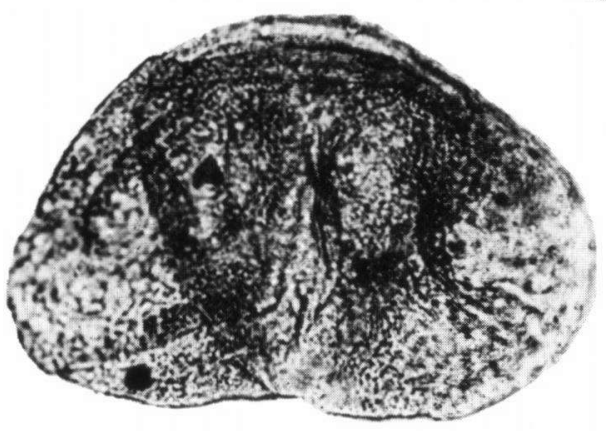

4

5

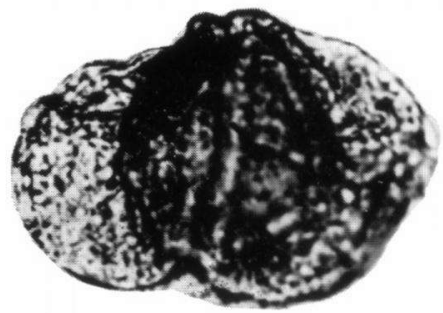

$6 a$

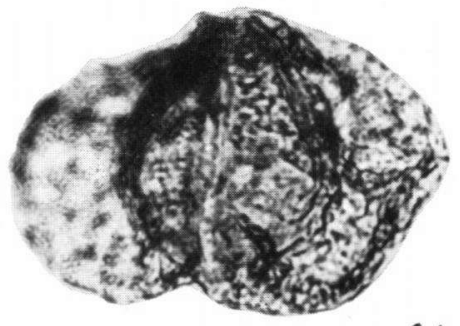

$6 \mathrm{~b}$

Plate 2. all specimens $600 \times$ except fig. $1(375 \times)$ 1. Falcisporites zapfei (69-TF-37);

2. id. (69-TF-35); 3. id. (69-TF-41); 4. Klausipollenites schaubergeri (69-TF-53);

5. Falcisporites triangularis n. sp., holotype (69-TF-31); 6a, b. Angustisulcites klausii n. sp., holotype (69-TF-32). 

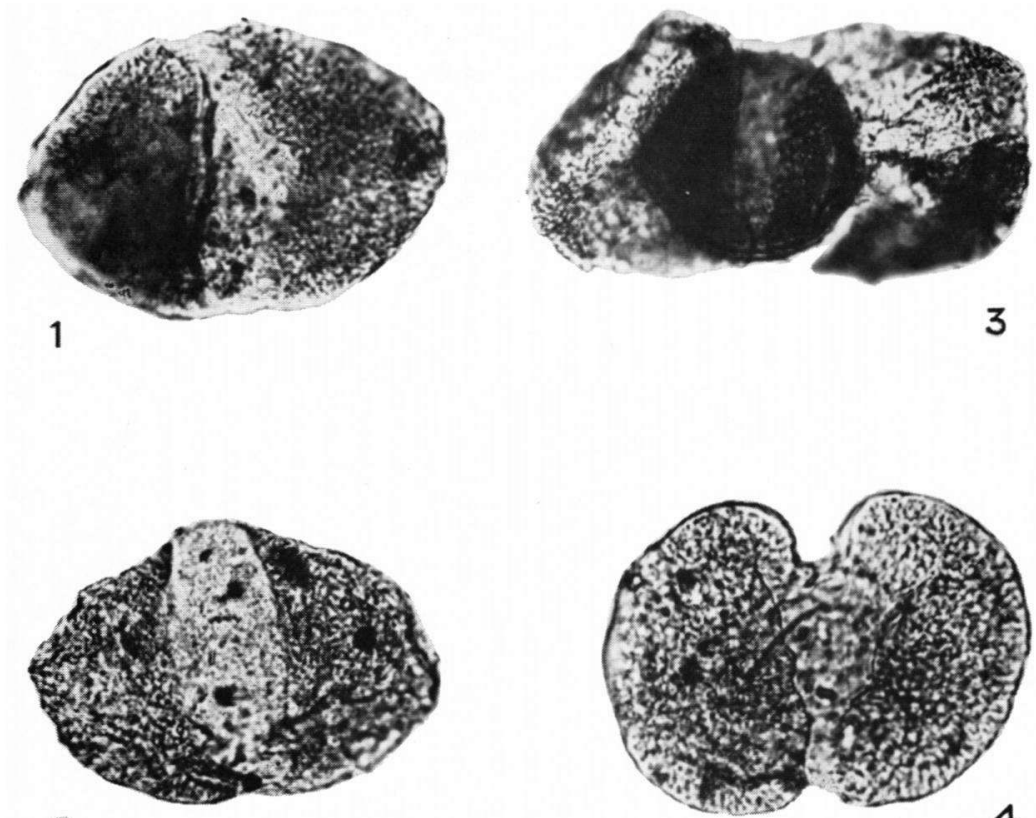

2
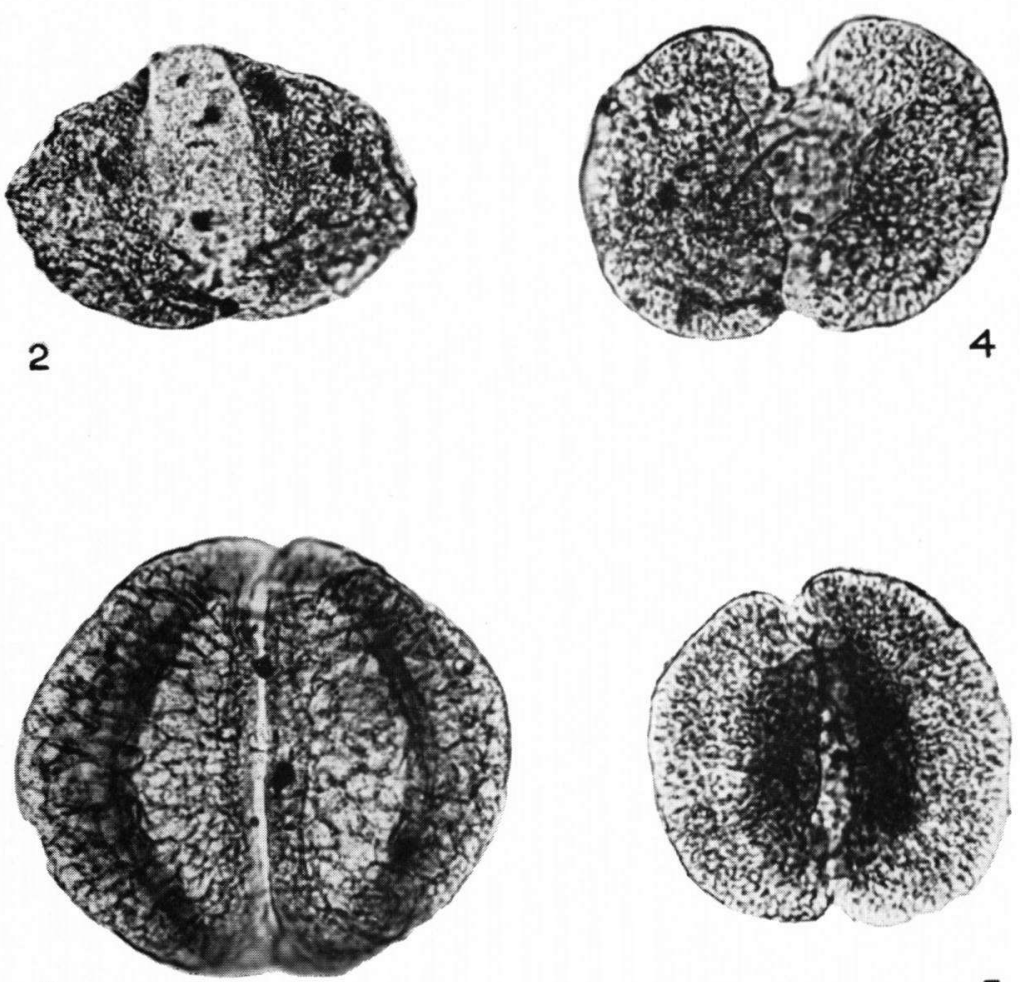

6

Plate 3. all specimens $600 \times$ except fig. $3(375 \times)$ 1. Labiisporites granulatus $(69-\mathrm{TF}-55)$; 2. id. (69-TF-94); 3. Platysaccus hengeloensis n. sp., holotype (69-TF-23); 4. Platysaccus papilionis, bleached with immersion oil (69-TF-72); 5. id., bleached with immersion oil (69-TF-21); 6. Favisporites tenuis, holotype. 


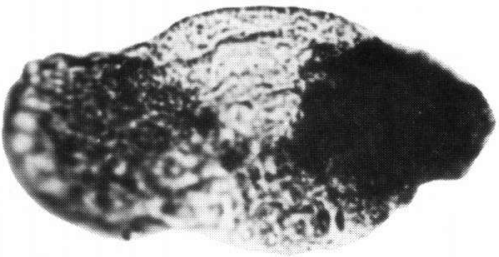

1

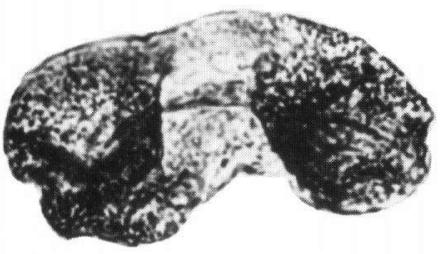

2
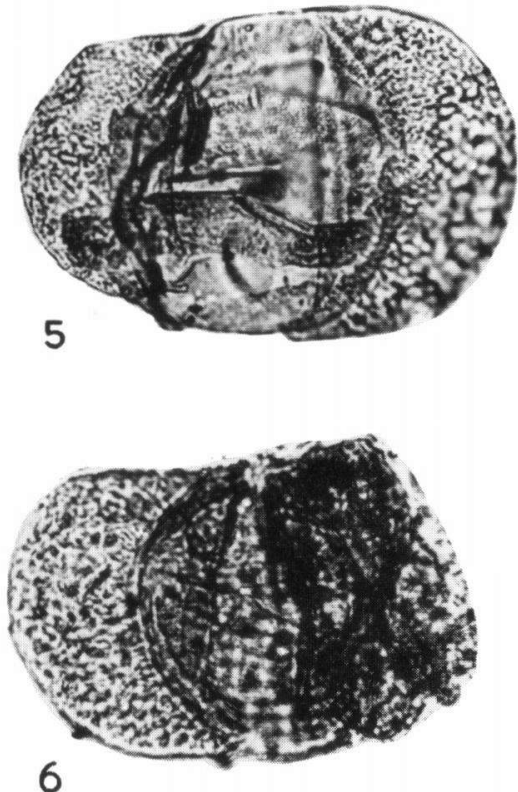

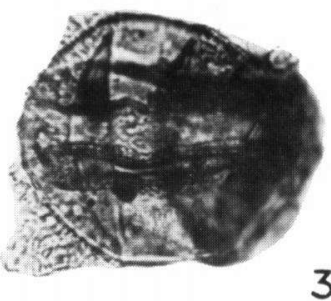

3
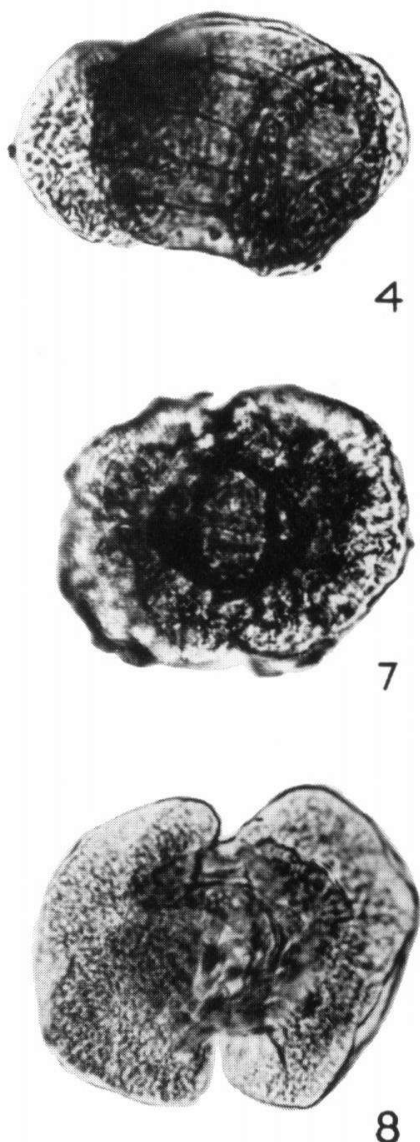

Plate 4. all specimens $600 \times 1$. Pityosporites devolvens (69-TF-58); 2. id. (69-TF-59);

3. Taeniaesporites noviaulensis $(69-\mathrm{TF}-15)$; 4. id. $(69-\mathrm{TF}-20)$; 5. id. $(69-\mathrm{TF}-18)$;

6. Striatites richteri (69-TF-01); 7. Taeniaesporites nubilus $(69-\mathrm{TF}-90)$; 8. id., bleached with immersion oil (69-TF-75). 

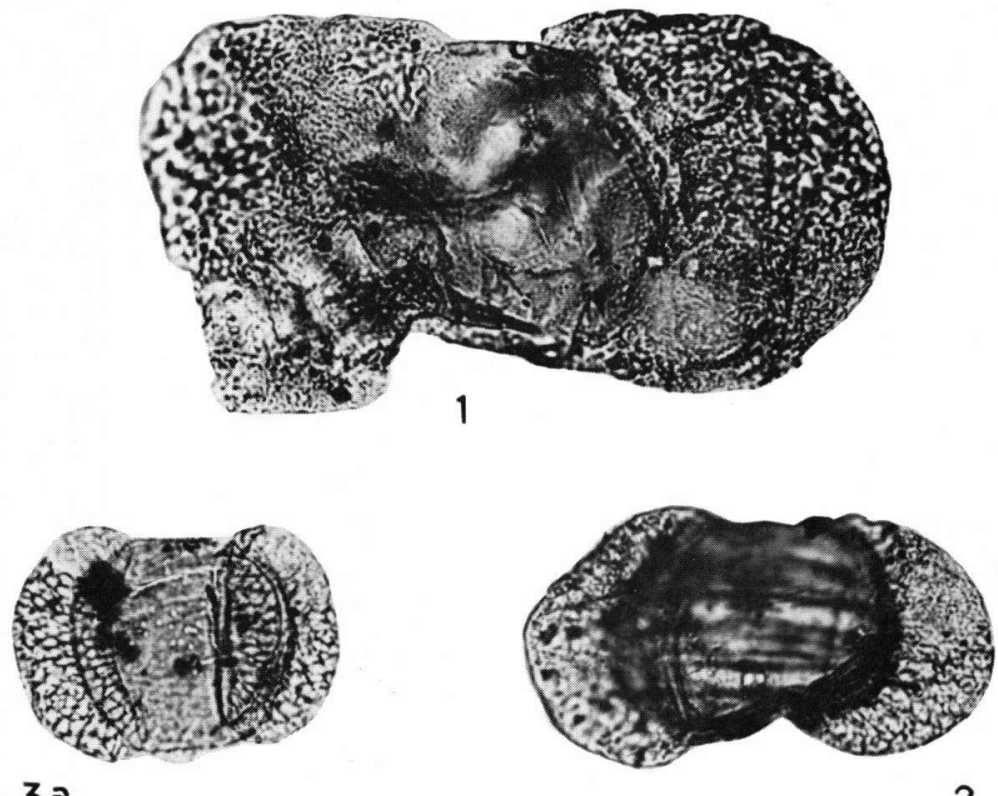

$3 a$

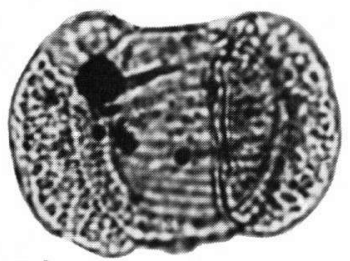

$3 b$
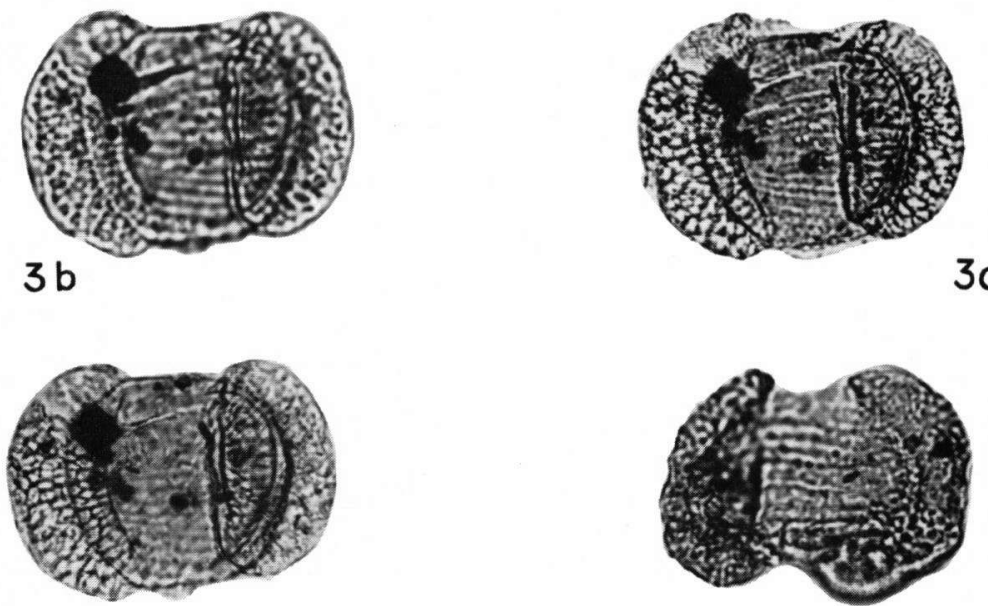

$3 d$

Plate 5. all specimens $600 \times$ except fig. 1. $(375 \times)$ 1. Falcisporites? grandis n. sp., holotype $(69-\mathrm{TF}-71) ; 2$. Taeniaesporites noviaulensis $(69-\mathrm{TF}-16) ; 3 \mathrm{a}, \mathrm{b}, \mathrm{c}, \mathrm{d}$ Protosacculina jansonii n. sp., holotype (69-TF-101); 4. id. (69-TF-02). 
the absence of a darker ovoid central body and he puts forward the theory that there are intermediate forms, indicating that these two species are different preservation states of pollen grains of the same plant. Such observations could not be made in our assemblages. The dark-coloured central body does not seem to be a very important distinguishing mark.

It seems that important features are: fine bladder reticulum and the roof-shaped rent in the intexine. Furthermore, we observed in most specimens narrow equatorial bladder connections.

Occurrence: Upper Permian: Germany, Austria, N. Italy, Hungary.

Lower Triassic: Austria, Netherlands.

\section{Jugasporites moersensis Grebe}

plate 1, fig. 4.

Holotype:

Jugasporites delasaucei moersensis Grebe, 1957, Geol. Jb., 73: 59, t 6. f 31 .

Synonym(?)

Limitisporites moersensis (Grebe) Klaus, 1963, Jb. Geol. B.-A., 106: 238, t 6. f 24.

A fairly rare species in our assemblages. Our specimens are very similar to those described and illustrated by Grebe.

In most cases it is difficult to see the roof-shaped laesura.

Grebe describes this species as subspecies of $\mathcal{f}$. delasaucei. In the opinion of the author it is a separate species differing from $\mathcal{F}$. delasaucei in its strong affinity to monosaccate pollen expressed by a very broad exoexinal strip interconnecting the bladders (this feature is absent in $L$. moersensis figured by KLAus, 1963).

Furthermore, this species differs from $\mathcal{F}$. delasaucei, as a distinct thickened bladder base is lacking.

Occurrence: Upper Permian: Germany, N. Italy(?). Lower Triassic: Netherlands.

\section{Infraturma Disacciatriletes Leschik emend. Potonié 1958}

Type species:

\section{KLAUSIPOLLENTTES Jansonius 1962}

Pityosporites schaubergeri Potonié \& Klaus, 1954, Geol. Jb., 68: 536, t 10 . f 7. Synonym:

Pityosporites Seward emend. Potonié \& Klaus (partim)

Falcisporites Leschik emend. Schaarschmidt (partim)

Klausipollenites schaubergeri (Potonié and Klaus) Jansonius plate 1, figs. 8; plate 2, fig. 4 .

Holotype:

Pityosporites schaubergeri Potonié \& Klaus, 1954, Geol. Jb., 68: 536, t 10 . f 7. 
Synonym:

Pityosporites schaubergeri Potonié \& Klaus; Klaus, 1955, Zschr. Deu. Geol. Ges., 105: 782, t 33. f 8, 11; Grebe, 1957, Geol. Jb., 73: 63, t 6. f 32, 33

Klausipollenites schaubergeri (Potonié \& Klaus) Jansonius, 1962, Palaeontographica, B, 110, B: 55; Grebe \& Schweitzer, 1962, Fortschr. Geol. Rheinl. Westf. Vorausdruck: 17, t 10. f 7-9.

Falcisporites schaubergeri (Potonié \& Klaus) Schaarschmidt, 1963, Palaeontographica, B, 113: 58, t 15. f 10-17.

Our specimens are in accordance with description and illustration of the holotype.

$$
\begin{array}{ccc}
\text { Size } & \text { range } & \text { mean } \\
\text { overall . . . } & 54-75 \times 39-46 & 61 \times 41 \\
\text { c.b. . . . . } & 35-54 \times 35-43 & 43 \times 36
\end{array}
$$
broad.

The exoexinal strip interconnecting the bladders is $1,0-1,5 \mu$

Occurrence: Upper Permian: Austria, Germany, N. Italy, Hungary

Lower Triassic: Austria, Netherlands.

\section{FALCISPORITES Leschik 1956 emend. Klaus 1963}

Type species:

Pityosporites zapfei Potonié \& Klaus 1954, Geol. Jb., 68: 538, t 10 . f 9.

Synonym:

Pityosporites Seward emend. Potonié \& Klaus 1954 (partim).

Falcisporites Leschik 1956

Klausipollenites Jansonius 1962 (partim)

Falcisporites Leschik emend. Schaarschmidt 1963 (partim)

According to Klaus (1963) this genus differs from Klausipollenites in its distinct thickened and folded bladder bases; an equatorial bladder connection is lacking.

Falcisporites zapfei (Potonié and Klaus) Leschik plate 2, figs. 1, 2, 3 .

Holotype:

Pityosporites zapfei Potonié \& Klaus, 1954, Geol. Jb., 68: 538, t 10, f 9.

Synonym:

Pityosporites zapfei Potonié \& Klaus; Klaus, 1955, Zschr. Deu. Geol. Ges., 105: 779, t 34. f 2, 3, 5 (non f 8, 9); Grebe, 1957, Geol. Jb., 73: 63, t 6. f 37, 38 (non f 36).

Falcisporites zapfei (Potonié \& Klaus) Leschik, 1956, Palaeontographica, B, 100: 136, t 22. f 7; Klaus, 1963, Jb. Geol. B.-A., 106: 332, t 18. f 85-87; Schaarschmidt, 1962, Palaeontographica, B, 113: 57, t 16. f 8-10.

Pityosporites nigracrestatus Hennelly, 1958, Proc. Linn. Soc. N.S.W., 83: 366, t 5. f 13-15. 


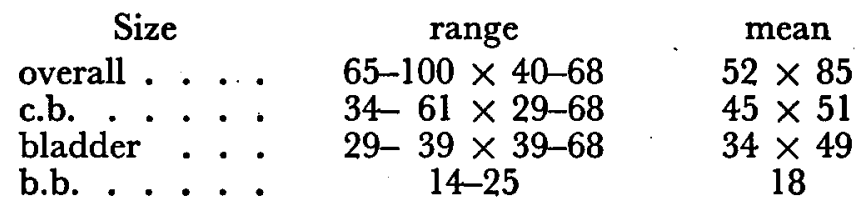

The size range of the longest axis given by Potonié and Klaus $(70-120 \mu)$ is slightly larger than in our assemblages.

The middle drawing of textfigure 10 of the same authors does not correspond with their description (see also Falcisporites triangularis n. sp.).

Figure 8 (KLaus 1955) does not belong to this species (see Falcisporites staplini (Jansonius) n. comb.).

Figure 9 (Kraus 1955) and figure 36 (GREBE, 1957) do not belong to this species; they show a greater resemblance with the genus Alisporites. A difference of our specimens with the holotype is the lighter colour; however, the specimen figured on plate 2, fig. 2 has been bleached with immersion oil, to show clearly the morphologic features at the bladder bases!

Occurrence: Upper Permian: Germany, Austria, Hungary, N. Italy.

Lower Triassic: Germany, Austria, Netherlands, Australia.

Falcisporites staplini (Jansonius) nov. comb.

Holotype:

Klausipollenites staplini Jansonius, 1962, Palaeontographica, B, 110: 56, t 12 . f 8. Synonym:

Pityosporites zapfei small variant Klaus, 1955, Zschr. Deu. Geol. Ges., 105: t 34 . $f 8$.

This species is rather common in the Hengelo assemblages but mostly in a bad state of preservation. They are in accordance with Jansonius' description. bases.

Characteristic features are its small size and very small bladder

Occurrence : Lower Permian: Tanganyika

Upper Permian: Germany

Lower Triassic: Canada, Netherlands.

\section{Falcisporites triangularis n. sp.}

plate 2, fig. 5 .

Holotype:

single-grain slide 69-TF-31; plate 2 , fig. 5. 
Description: This characteristic species is rare in our assemblages. Perhaps because of their particular central body shape most specimens are compressed equatorially instead of proximo-distally (the most common preservation form of bisaccate pollen grains). This description is based on specimens in equatorial view.

Size of the holotype:

$$
\begin{array}{llr}
\text { overall . . . . } & 102 \times 65 \\
\text { c.b. . . . . . } & 61 \times 65
\end{array}
$$

Overall outline bean-shaped. Central body rounded triangular (round in proximo-distal view), with thin fine granulate exine (less than $1 \mu$ thick). Finely reticulate bladders; mesh width about $1 \mu$.

Bladder bases converge strongly to the distal pole, delimitating a narrow $(5 \mu)$ germinal furrow. The width of the germinal furrow is of about the same size as in the pollen genera Alisporites and Favisporites.

Discussion: Distinguishing mark between $F$. zapfei and $F$. triangularis is the form of the central body and the finer reticulum of the bladders. Our specimens resemble slightly the middle drawing of $F$. zapfei in textfigure 10 in the article of Potonié and Klaus (1954). We did not observe such a central body shape in specimens of $K$. zapfei.

The description of $K$. zapfei by Potonié and Klaus does not give clear evidence of the existence of such central body forms.

Other authors did not figure such a central body shape of $K$. zapfei either.

Occurrence: Lower Triassic: Netherlands.

Falcisporites? grandis n. sp.

plate 5 , fig. 1 .

Holotype:

single-grain slide 69-TF-71; plate 5, fig. 1 .

Description:

\begin{tabular}{ccc}
\multicolumn{1}{c}{ Size } & range & mean \\
overall . . . . & $140-209 \times 54-108$ & $157-82$ \\
c.b. . . . . & $51-86 \times 43-86$ & $72-72$ \\
bladder... & $57-82 \times 54-108$ & $69-82$ \\
b.b. . . . . & $29-39$ & 33,5
\end{tabular}

Bisaccate pollen grains belonging to this species are the biggest in our assemblages.

Overall outline elongated elliptical to rounded rectangular. Gentral body round, infrapunctate to very fine infrareticulate, with $3,5-5 \mu$ broad exine.

The bladders are only slightly larger than the central body and have a fine, radially arranged infrareticulum. The intramarginal overlap is small and it ranges between 20 and $30 \%$. 
The straight bladder bases are not or only slightly thickened, often indistinct, delimitating a very wide germinal area.

The distance between the bladder bases is wider than in all other species of Falcisporites.

Discussion: $F$. grandis n. sp. differs from other species of the genus Falcisporites in its larger dimensions.

As a characteristic crescent-shaped thickening at the bladder bases is absent, the assignment of this species to Falcisporites is doubtful. Perhaps a new genus has to be created for this species.

Occurrence: Lower Triassic: Netherlands.

PLATYSACGUS Naumova emend. Potonié and Klaus 1954 Type species:

Platysaccus papilionis Potonié \& Klaus, 1954, Geol. Jb., 68: 539, t 10 . f 12.

Platysaccus papilionis Potonié and Klaus

plate 3 , figs. 4,5 .

Holotype:

Platysaccus papilionis Potonié \& Klaus, 1954, Geol. Jb., 68: 539, t 10 . f 12. Synonym:

Platysaccus papilionis Potonie \& Klaus; Klaus, 1955, Zschr. Deu. Geol. Ges., 105: 781, t 33, f 12; Grebe, 1957, Geol. Jb., 73: 64, t 6. f 39-41; (?) Klaus, 1963, Jb. Geol. B.-A. 106: 337, t 7, f 33.

Platysaccus of. papilionis Potonié \& Klaus; Jansonius, 1962, Palaeontographica, B, 110: 54, t 12. f 17-20; Balme, 1963, Palaeontology, 6: 25, t 6. f 12 .

Platysaccus umbrosus Leschik, 1956, Palaeontographica, B, 100: 136, t 22. f 6.

Remarks: Our specimens differ from the holotype in that the central bodies always have a lighter colour. Moreover, the specimens figured in this paper have been bleached with immersion oil to show the morphologic features clearly.

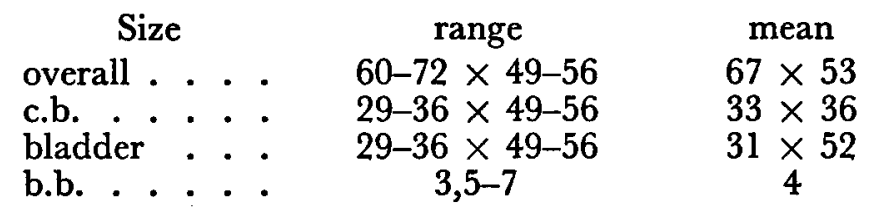

The dimensions are much smaller than those of the holotype (longest axis $106 \mu$, central body about $35 \mu$ ) and resemble more those given by JANsonius (1962).

The size range stated by Poтоnié and KLaus (1954) for this species is extremely wide: 33-200 $\mu$. The present author is of the opinion that Potonié and Klaus included different species within the name Platysaccus papilionis.

Occurrence: Upper Permian: Central Europe, Hungary. Lower Triassic: Canada, Australia, Netherlands. 
Platysaccus hengeloensis n. sp. plate 3 , fig. 3.

Holotype:

single-grain slide 69-TF-23; plate 3 , fig. 3 .

Derivatio nominis:

named for the city Hengelo, Netherlands.

Description:

\begin{tabular}{lcc}
\multicolumn{1}{c}{ Size } & range \\
overall .... & $90-132 \times 37-72$ \\
c.b. . . . . & $24-57 \times 22-56$ \\
bladders . . . & $31-57 \times 31-70$ \\
b.b. . . . . & $7-15$
\end{tabular}

The ratio between longest and shortest axis is about 2 to 1 . Central body round, light or dark brown, with $1,5 \mu$ thick exine. Straight, thickened bladder bases, converge slightly to distal pole. Rather large distance between the bladder bases, always larger than in $P$. papilionis.

Approximately semi-elliptical bladders with rather fine, radially arranged infrareticulum. Perhaps this bladder shape is due to squashing, and was originally semi-circular in polar view, as in $P$. papilionis.

Discussion: $P$. hengeloensis $n$. sp. differs from $P$. papilionis in its relatively large distance between the bladder bases, thinner central body exine, and finer bladder reticulum. In the Hengelo assemblages, $P$. hengeloensis is bigger than $P$. papilionis.

Occurrence: Lower Triassic: Netherlands.

Type species:

ANGUSTISULCITES novum genus

Angustisulcites klausii n. sp.

Diagnosis: bisaccate pollen grains with round central body. Bladders as big as or bigger than central body, proximally attached at equator and not equatorially interconnected. The straight bladder bases are unthickened and distally enclose a narrow deep sulcus.

Discussion: This genus differs from Platysaccus in its smaller bladders and narrow, deep distal sulcus.

Angustisulcites klausii n. sp.

plate 2, figs. 6a, b.

Holotype:

single-grain slide 69-TF-32; plate 2 , fig. $6 \mathrm{a}, \mathrm{b}$.

Derivatio nominis:

Dr. W. Klaus, Vienna, Austria. 
Description:

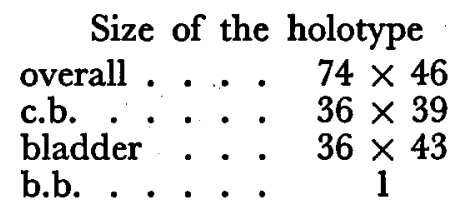

Overall outline elliptical. Brown round central body with smooth thick $(3,5 \mu)$ exine. Bladders somewhat lighter coloured, proximally attached at equator of central body, distally attached at the distal pole. The bladders are punctate or fine reticulate; the reticulum is slightly radially orientated. Distally the bladders enclose a very narrow and deep sulcus at the distal pole (about $1 \mu$ broad). The bladderbases are straight and unthickened or only slightly thickened.

Occurrence: Lower Triassic: Netherlands (rare).

\section{LABISPORITES Leschik emend. Klaus 1963}

Type species:

Labiisporites granulatus Leschik, 1956, Palaeontographica, B, 100: 137, t 22. f 1.

Remarks: KLAUS (1963) emended this genus and added to the generic diagnosis by Leschik as characteristic feature: a small distal rent in the exoexine and intexine.

This feature is clearly visible in textfigure 23 (Klaus, 1963) but neither visible in the holotype of $L$. granulatus Leschik, nor in the specimens of $L$. granulatus figured by Klaus.

Also in the Hengelo assemblages, such a feature could not be observed.

Labiisporites granulatus Leschik

plate 3, figs. 1, 2.

Holotype:

Labiisporites granulatus Leschik, 1956, Palaeontographica, B, 100: 137, t 22 . f 1 . Synonym:

Labiisporites granulatus Leschik; Klaus, 1963, Jb. Geol. B.-A., 106: 288, t 7. f 27-29.

Remarks:

Size

range

mean

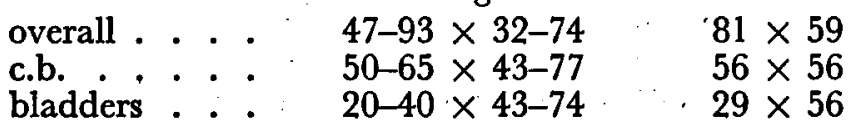

Generally our specimens are in good accordance with the holotype. The central body shape of the holotype (longest axis perpendicular to longest axis of pollen grain) is rather uncharacteristic, but in our 
material we also occasionally observed this central body shape. Common in our assemblages.

Occurrence: Upper Permian: Germany, Northern Italy. Lower Triassic: Netherlands.

PITYOSPORITES Seward 1914 emend. Manum 1960

Type species:

Pityosporites antarcticus Seward, 1914, Nat. Hist. Rep. Br. Antarct. Exp. 1910, Geol.: 23, t 8. f 45 .

Synonym:

Pinuspollenites Raatz 1937

Remarks: The redescription of $P$. antarcticus by Manum allows a more precise diagnosis of the genus Pityosporites: bisaccate pollen grains, bladders over half-circular without equatorial connection, strongly distally displaced.

Pityosporites Seward emend. Potonié and Klaus 1954 does not agree with this diagnosis and is considered to include the genera Falcisporites Leschik and Klausipollenites Jansonius.

Pityosporites devolvens Leschik plate 4, figs. 1, 2.

Holotype:

Pityosporites devolvens, Leschik, 1955, Schw. Pal. Abh., 72: 61, t 9. f 6.

Description:

$\begin{array}{ccc}\text { Size } & \text { range } & \text { mean } \\ \text { overall . . . . } & 69-115 \times 36-56 & 84 \times 45 \\ \text { c.b. . . . . . } & 43-61 \times 32-57 & 57 \times 44 \\ \text { bladders . . . } & 25-50 \times 36-57 & 30 \times 44 \\ \text { b.b. . . . . . } & 18-32 & 24\end{array}$

Overall outline about elliptical. Central body oval, longest axis in same direction as longest axis of pollen grain, proximal face with an inflated "cap" of exoexine. Bladders proximally attached at equator of central body, distally approximately at the distal pole.

Bladder reticulum fine. Bladder bases straight, distinct, thickened. Bladders dark brown, central body white or yellow.

Occurrence: Lower Triassic: Netherlands. Upper Triassic: Switzerland.

FAVISPORITES Leschik emend.

Type species:

Favisporites lucidus Leschik 1956, Palaeontographica, B, 100: 137, t 22. f 13.

Leschik's diagnosis of the genus Favisporites reads: "Luftsacksporen 
mit sehr groszen Netzlumina". The type species has a mesh width of about 6-8 $\mu$.

However, Favisporites tenuis Leschik has smaller meshes. On the other hand, there are many other genera with big meshes, so it seems necessary to emend this genus and to give a more precise diagnosis:

Bisaccate pollen grains with a big round central body, in proximodistal view almost totally embraced by the bladders. The bladders have a coarse reticulum; the mesh width may vary from the bladder periphery up to the bladder base. Bladder size slightly bigger than the half of the central body. Bladder bases distinct or indistinct delimitating a narrow germinal furrow. Intramarginal overlap always over $50 \%$. Proximally the bladders are attached to the central body at the equator.

Discussion: This genus resembles most Alisporites Daugherty emend. Potonié and Kremp, although it differs in its large intramarginal overlap, smaller distance between the bladder bases and coarser bladder reticulum.

Favisporites tenuis Leschik 1956

plate 3, fig. 6 .

Holotype:

Favisporites tenuis Leschik, 1956, Palaeontographica, B, 100: 138, t 22. f 14.

Description:

Size range

mean

overall ....

$67-87 \times 66-81$

$79 \times 72$

c.b. . . . .

$50-63 \times 63-76$

bladder . .

$30-41 \times 63-81$

b.b. . . . .

3-6

$59 \times 70$

$46 \times 72$

4,5

Some observations may be added to the species diagnosis of Leschik: The intramarginal overlap ranges between 70 and $95 \%$. The bladders interconnect equatorially with a 3-5 $\mu$ broad strip of exoexine. The. bladders enclose distally a rather deep and narrow sulcus. At the bladder bases the width of the reticulum meshes is about $1,5 \mu$, getting wider (until about $7 \mu$ ) up from the bladder bases to the periphery of the bladders. The central body exine is about $3 \mu$ thick.

Discussion: Although our specimens are slightly bigger they are very similar to Leschik's holotype.

Occurrence: Upper Permian: Germany, Hungary

Lower Triassic: Netherlands.

\section{Infraturma Striatiti Pant 1954}

Remarks: HART (1963) summarized the knowledge about striate pollen species and proposed a new generic classification mainly based on generic names defined by Russian authors. Generally these names 
are very poorly defined or they are nomina nuda. However, some names have been published according to the rules of the International Code of Botanical Nomenclature, others have been validated by a redescription.

Protohaploxypinus Samoilovich emend. Hart, Striatopodocarpites Zoritcheva and Sedova emend. Sedova and Striatoabietites Zoritcheva and Sedova emend. Sedova seem to have priority over a lot of other generic names; including those mentioned in this paper; however, the names suggest a phylogenetic relationship with recent plants with bisaccate pollen grains, which relationship is very doubtful.

As the study of Hart is still unpublished (only mimeographed) the use of his classification would be very confusing; therefore the author follows the classification of Jansonius, which-up to now-certainly is the most appropriate one.

TAENIAESPORITES Leschik 1955 emend. Jansonius 1962

Type species:

Taeniaesporites kraeuseli Leschik, 1955, Schw. Pal. Abh., 72: 59, t 8. f 1.

Synonym:

Lunatisporites Leschik 1955

Lueckisporites Potonié \& Klaus 1954 (partim)

Lueckisporites Potonié \& Klaus 1954 emend. Potonié 1958

Pollenites sulcatus Pautsch 1958

Striatites Pant 1954 emend. Jansonius 1962 (partim)

Taeniaesporites Leschik 1955 emend. Klaus 1963 (partim)

Taeniaesporites noviaulensis Leschik

plate 4, figs. $3,4,5$; plate 5 , fig. 2 .

Holotype:

Taeniaesporites noviaulensis Leschik, 1956, Palaeontographica, B, 100: 134, t 22. f 1. Şynonym:

Taeniaesporites novimundi Jansonius, 1962, Palaeontographica, B, 110: 63, t 13. f $19-25$

Taeniaesporites sp. of. noviaulensis Leschik, Balme, 1963, Paleontology, 6, 1: t 6 . f 4-6.

$\begin{array}{cccc}\text { Size } & \text { range } & \text { mean } \\ \text { overall . . . } & 72-84 \times 45-52 & 80 \times 50 \\ \text { c.b. } . . & 48-60 \times 39-52 & 52 \times 47 \\ \text { bladder } . \cdot . & 25-36 \times 45-52 & 31 . \times 45 \\ \text { b.b. . . . . } & 12-22 & 19\end{array}$

Remarks: Our specimens correspond with the illustration of the holotype. However, the dimensions of the holotype do not fall within the size range of our specimens.

Jansonius described $T$. novimundi which should primarily differ from $T$. noviaulensis in its smaller size, furthermore in its slightly finer bladder reticulum. However, the paratypes of $T$. novimundi, stored in 
the Botanical Museum at Utrecht, have the same reticulum as the holotype of $T$. noviaulensis; many Canadian specimens fall within the size range mentioned above but their mean size is smaller.

As the size ranges are overlapping each other to a high degree, there is no clear feature to distinguish these two species.

For this reason the author considers $T$. novimundi synonymous with T. noviaulensis.

Occurrence: Upper Permian: Germany, England, N. Italy. Lower Triassic: Canada, Australia, Netherlands.

Taeniaesporites nubilus (Leschik) nov. comb.

plate 4 , figs. 7,8 .

Holotype:

Jugasporites nubilus Leschik, 1956, Palaeontographica, B, 100: 133, t 21 . f 14. Synonym:

Striatites? nubilus (Leschik) Jansonius, 1962, Palaeontographica, B, 110: 69, t 14. f 20.

Remarks: Only a few specimens are observed in the samples investigated. Their size corresponds with that of the holotype. We did not find evidence for assignment to Jugasporites (bisaccate pollen grains with roof-shaped rent on the central body). Jansonius made the same observation in Lower Triassic Canadian assemblages but states that he found this feature in samples from elsewhere.

Leschik's holotype has at least three taeniae, perhaps four; in our assemblages specimens with three or four taeniae could be observed. Jansonius supposed that this species should be assigned to the genus Striatites as he could see only a faint indication of taeniae (due to the dark colour of the central body).

On account of the number of taeniae here this species is assigned to the genus Taeniaesporites. The specimen figured in plate 4 , fig. 8 has been bleached with immersion oil.

Occurrence: Upper Permian: Germany, England Lower Triassic: Canada, Netherlands.

STRIATITES Pant 1955 emend. Jansonius 1962

Type species:

Pityosporites sewardii Virkki, 1938, Proc. Ind. Acad. Sci., B, 6: 429, f 2 A.

Synonym:

see Jansonius, 1962, Palaeontographica, B, 110: 65

Furthermore:

Hindipollenites Bhardwaj 1962

Strotersporites Wilson 1962

Strotersporites. Wilson 1962 emend. Klaus 1963

Striatites richteri (Klaus) Jansonius plate 4, fig. 6 . 
Holotype:

Lueckisporites richteri Klaus, 1955, Zschr. Deu. Geol. Ges., 105: 778, t 33 . f 1. Synonym:

Lueckisporites richteri Klaus; Grebe, 1957, Geol. Jb., 73: 62, t 5, f 17-19

Taeniaesporites richteri (Klaus) Leschik, 1956, Palaeontographica, B, 100; 135, t 22. f 8 .

Striatites richteri (Klaus) Jansonius, 1962, Palaeontographica, B, 110: 66, t 14. f $21-22$

Strotersporites richteri (Klaus) Klaus, 1963, Jb. Geol. B.-A. 106, 1: 316, t 15. f 76, 77 .

Remarks: Our specimens are fairly similar to the holotype. Generally they have a smaller number of taeniae than those described and figured by Klaus and Jansonius (approximately 18).

Furthermore, our specimens differ from the holotype in that they have a round central body. Jansonius, of Canadian assemblages also stated that a circular central body would be more characteristic for this species than the rounded oval shape of the central body of the holotype. He explained this appearance as caused by squashing.

Occurrence: Upper Permian: Germany, Northern Italy, Hungary.

Lower Triassic: Canada, Austria, Netherlands.

\section{PROTOSACGULINA Maljavkina 1953}

Type species:

Protosacculina glabrescens var. glabrescens ("rhetica") Maljavkina, 1953, Trudy V.N.I.G.R.I., n. ser., 75: 144 , t 31 . f 3 .

Protosacculina jansonii n. sp.

plate 5 , figs. $3 a, b, c, d, 4$.

Holotype:

single-grain slide 69-TF-101; plate 5, fig. $3 a, b, c$, d.

Derivatio nominis:

Dr. J. Jansonius, Calgary, Alberta, Canada.

Description :

Size holotype:

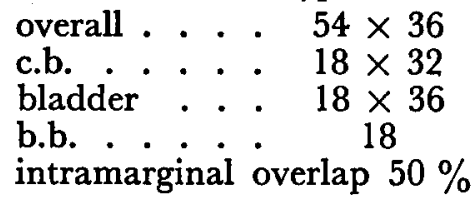

Central body oval to elongated hexagonal, with proximal exoexinal cap split by approximately $10-15$ laesurae (less than $0,5 \mu$ broad), running the full length. The infrapunctate taeniae are much broader than the laesurae; their width ranges between 1 and $4 \mu$. 
The semicircular bladders have. a rather fine infrareticulum; mesh width approximately $1,5 \mu$.

The infrareticulum is slightly radially orientated at the bladder bases only and the mesh width close to the bladder bases is slightly finer than at the other parts of the bladders.

The bladder bases are straight, unthickened. Distance between the bladder bases may range between 18 and $28 \mu$; this distance is in relation to the central body size larger than that of species of the genus Striatites.

Discussion: On account of the small bladders and the large distance between the bladder bases this new species is assigned to the genus Protosacculina. It shows some differences with the diagnosis of the genus Protosacculina (see JANsonius, 1962): radially orientated infrareticulum at the bladder bases.

$P$. jansonii differs from $P$. wodehousei Jansonius in its shape of the central body (less elongated), it differs from $P$. glabrescens in its larger number of taeniae, it differs from P. multistriatus (Balme and Hennelly) Potonié in its smaller number of taeniae.

$P$. jansonii shows strong resemblance with $c f$. Striatopinites Zoritscheva and Sedova, figured by Pautsch, 1958, Micropal., 4: t 1. f 9.

Occurrence: Lower Triassic: Netherlands.

\section{DESCRIPTION OF THE POLLEN ASSEMBLAGES AND COMPARISON WITH OTHER PERMIAN AND TRIASSIG ASSEMBLAGES}

The rock salt samples investigated contain spore-pollen complexes characterized by a high percentage of bisaccate pollen grains; in this way they resemble Permian and Triassic complexes described by other authors. However, in our assemblages this percentage is very high, approximately $99 \%$.

The other one percent consists of spores, mainly belonging to the turma Triletes Reinsch 1881 emend: Potonié and Kremp 1954. Hystrichosphaerideae, pointing to a marine sedimentation environment, are observed in three samples only (in one sample in a large quantity). They may be assigned to Micrhystridium Deflandre emend. Staplin. Up to now Hystrichosphaerideae in Lower Triassic spore-pollen complexes have only been known from Canada (Jansonius, 1962), Australia (Balme, 1963).

A feature which distinguishes our assemblages from those described by other authors is the percentual composition of the pollen complexes, particularly the ratio between striate and non-striate pollen. This feature is reproduced in Fig. 3, indicating the ratio striate to non-striate pollen in all samples investigated.

From this figure it is evident that the non-striate outnumber the striate pollen. Non-striate pollen average approximately $91 \%$, the striate pollen $8 \%$. In most Upper Permian and Lower Triassic 


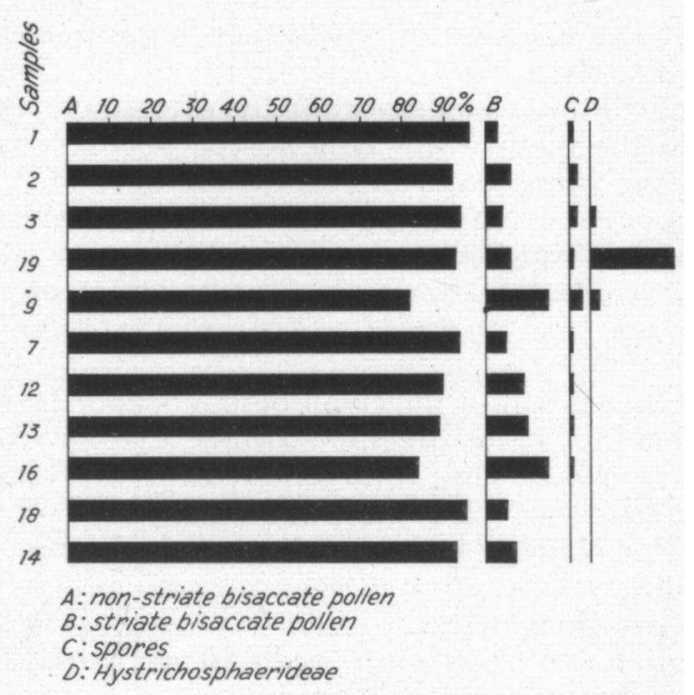

Fig. 3. Percentual composition of the Hengelo assemblages.

assemblages described up to now striate pollen grains outnumber to a high degree the non-striate ones. From publications by Klaus the striate pollen percentage seems indeed to decrease into the upper part of the Lower Triassic, but nevertheless it covers a very important constituent of the assemblages. The following scheme shows the composition of some European samples (after data of Klaus and Stuhl).

\begin{tabular}{l|l|c|c|c}
\hline & & striate & non-striate & totally \\
\hline Röt (Scythian) & Holland & 8 & 91 & 99 \\
Werfen (Scythian) & Germany & 18 & 82 & 100 \\
Zechstein (Saxonian) & Austria & 50 & 50 & 100 \\
& Austria & 50 & 50 & 100 \\
& Hungary & 45 & 45 & 90 \\
& Germany & 55 & 45 & 100 \\
\hline
\end{tabular}

LESGHIK (1956) states that the striate pollen outnumber the nonstriate ones in the German Zechstein but he does not give percentages. From table 3 (Jansonius, 1962) it is clear that a same composition characterizes the Lower Triassic Canadian assemblages.

A study on Lower Triassic assemblages of Western Australia by BALME (1963) shows the same feature; in 17 samples the striate pollen (mainly Taeniaesporites noviaulensis) average approximately $95 \%$ of the bisaccate pollen grains. However, the ratio between spores and pollen (1:7) differs from most of the other described assemblages. From these data it is clear that the composition of our assemblages resembles most the Röt assemblages from Hannover (Germany) described by Klaus. 
A second difference from the assemblages described up to now by other authors is the composition of the group of striate pollen. In the European Upper Permian and Lower Triassic assemblages Lueckisporites virkkiae predominates within this group, which species is totally lacking in our assemblages.

The group of non-striate pollen has some affinity with that in the Upper Permian assemblages from Germany, Austria, Northern Italy and Hungary (Fig. 4). Klaus (1955b, 1963), Stuhl (1962) and SchaARschmid (1963) state that Klausipollenites schaubergeri, Falci-

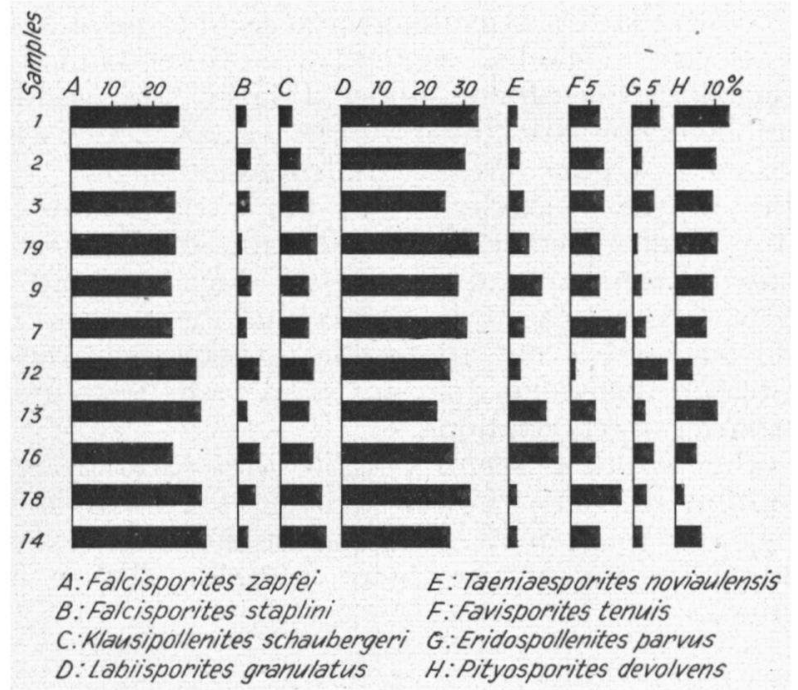

Fig. 4. Percentual distribution of the most important species.

sporites zapfei and fugasporites delasaucei average $40-50 \%$ in their assemblages. In our assemblages this group averages about $40 \%$. However, it is noticeable that there are some non-striate species common in our assemblages which were not observed in large quantities by the authors mentioned above: Labiisporites granulatus (average 28,3\%), Favisporites tenuis (average 7,4\%) and Pityosporites devolvens (average $7,7 \%$ )..

KLAUS $(1953 \mathrm{~b}, \mathrm{c})$ states that the Lower Triassic is characterized by the non-striate pollen species Pityosporites hallstattensis ${ }^{1}$ ) but he recently (1963) denied the presence of it in the Röt assemblage from Hannover. This species does not occur in the Hengelo assemblages.

1) The name $P$. hallstattensis has not been published in accordance to the rules of the International Code of Botanical Nomenclature (art. 34, 38) and consequently it was not valid. It has been figured by KLAus (1953a, $t 2$. f 25) without name. The name has been assigned by KLAUs (1953b, p. 166) without description or holotype. Recently, Kusus (1963) described and figured the same(?) species under another name: Gigantosporites hallstattensis. 
According to Klaus (1953b), in Austria and Southern Germany this species is getting rapidly more important from the lower to the upper part of the Lower Triassic. It may average 60-70\% in the Röt. On the other hand, the percentage of Falcisporites zapfei, Klausipollenites schaubergeri and $\mathcal{F}$ ugasporites delasaucei decreases rapidly and averages only a few percents in the Röt.

From these data published by other authors the differences with the Hengelo assemblages are clear. The striate pollen percentage has the greatest similarity with that of the Röt assemblage described by KLAUs (1953), whereas the non-striate pollen do not have much resemblance with the Röt assemblage and seem to have more characteristics of Zechstein pollen assemblages. Resemblance could be found neither with the alpine Upper Triassic and Middle Triassic pollen assemblages nor with Dutch Middle Triassic pollen assemblages, nor with Swedish Upper Triassic pollen assemblages.

From this one may conclude that the trend of flora evolution observed by Klaus (decreasing percentage of Falcisporites zapfei, Klausipollenites schaubergeri and fugasporites delasaucei, and increasing percentage of "Pityosporites hallstattensis" in the Lower Triassic) is only a local one and is not applicable to extensive areas.

For this reason this trend does not seem to be very useful for extensive stratigraphic correlations.

On the other hand, it seems possible that such discrepancies in the composition of these Lower Triassic spore-pollen complexes indicate that something may be wrong in the present stratigraphic correlations which are largely based on similarities in lithological characteristics.

\section{Table 1}

Quantitive distribution of bisaccate pollen species in the Hengelo assemblages.

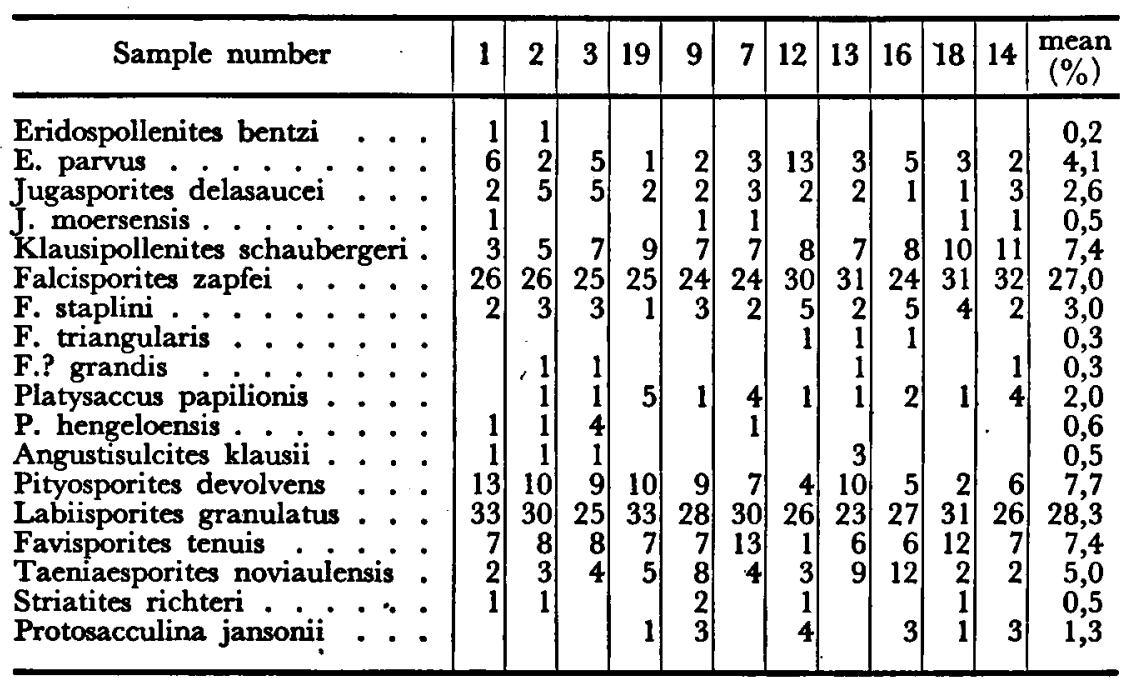




\section{ACKNOWLEDGEMENT}

I am indebted to Dr. F. P. Jonker for his keen interest in palynological research which resulted in the publication of this paper and to Dr. W. Punt whose generous aid greatly stimulated this investigation. I am under great obligation to Dr. G. Leschik (Saarbrücken) and Dr. W. Klaus (Vienna) who kindly placed at my disposal the holotypes of the species described by them.

I should like to express my thanks to Dr. J. Jansonius (Calgary, Alberta, Canada) for his critical reading of the text.

Thanks are due to the "Koninklijke Nederlandse Zoutindustrie" who furnished the rock salt samples, and to the "Geologische Dienst" (Haarlem) where the photomicrographs have been made.

\section{REFERENCES}

Alpern, B. et al. 1958. Description de quelques microspores du Permocarbonifere français. Rev. Micropal. 1: 75-86.

AndreEva, E. M. 1953. Spores and pollen from the coals of the Tunguss basin (in Russian). Paleontologija i stratigrafija: 102-125.

et al. 1956. Atlas of the leading forms of the fauna and flora of the Permian deposits in the Kuznetsk basin. V.N.I.G.I. (VSEGEI), Minist. geol. ix ochr. nelr. SSSR: 233-286.

Balme, B. E. 1952. The principal microspores of the Permian coals of Collie. Geol. Surv. West. Austr. Bull. 105: 164-201.

and J. P. F. Hennelly. 1955. Bisaccate, sporomorphs from Australian Permian coals. Austr. J. Bot: 3: 89-98.

and -1956 . Monolete, monocolpate and alete sporomorphs from Australian Permian sediments. Austr. J. Bot. 4: 54-67.

and $1956 \mathrm{~b}$. Trilete sporomorphs from Australian Permian sediments. Austr. J. Bot. 4: 240-260.

BhardwaJ, D. C. 1954. Einige neue Sporengattungen des Saarkarbons. Neues Jb. Geol. Pal., Mh. 11: 512-525.

1955. The spore genera from the Upper Carboniferous coals of the Saar and their value in stratigraphical studies. Palaeobotanist, 4: 119-149.

1957. The spore flora of the Velener Schichten (Lower Westfalian D in the Ruhr Coal Measures) Palacontographica B, 102: 110-138.

1960. The miospore genera in the coals of Raniganj Stage (Upper Permian) India. Palaeobotanist. 9: 68-108.

BOER, J. DE. 1963. The geology of the Vicentinian Alps. Geologica Ultraiectina 11 (Med. Min.-Geol. Inst. Utrecht).

Brown, G. A. 1960. Palynological techniques. Baton Rouge, La.

Chaloner, W. G. 1962. British Rhaetic and Triassic spores (abstract only) Pollen et Spores. 1: 339 .

Daugherty, L. H. 1941. The Upper Triassic flora of Arizona. Carnegie Inst. Wash. 526.

DeÁ, M. H. 1959. Experimental palynological investigations of gypsum from the Messek mountain range (in Hungarian, with German summary). Bull. Hung. Geol. Soc. 89: 170-173.

Dulhunty, F. 1946. Principal microspore types in the Permian coals of New South Wales. Proc. Linn. Soc. N.S.W. 70: 147-157.

Dumart, P. et al. 1963. Nouvelle méthode de concentration des pollen dans les sédiments pauvres par microflottation. C. R. Ac. Sci. Fr. 256: 231-233.

Grebe, H. 1957. Zur Mikroflora des niederrheinischen Zechsteins. Geol. Jb. 73: 51-74.

- und H. J. Schwerrzer. 1962. Die Sporae dispersae des niederrheinischen Zechsteins. Fortschr. Geol. Rheinl. u. Westf.: 1-23.

Hennelly, J. P. F. 1958. Spores and pollen from a Permian-Triassic transition, N.S.W., Proc. Linn. Soc. N.S.W. 83: 363-369. 
Inosova, K. I. and L. P. Nesterenko. 1955. On the spores and pollen of the Permian deposits of the Donetz basin (in Russian). Dokl. Ak. Nauk SSSR. 100: 779-782.

Jansontus, J. 1962. Palynology of Permian and Triassic sediments, Peace River Area, Western Canada. Palaeöntographica B, 110: 35-98. and F. L. Staplin. 1962. Late Paleozoic saccate pollen; structure and relationships (abstract only) Pollen et Spores. 4: 353-354.

JizBA, K. M. M. 1962. Late Paleozoic bisaccate pollen from the United States Midcontinent Area. J. Pal. 36: 871-887.

KLAUS, W. 1953a. Zur Einzelpraeparation fossiler Sporomorphen. Mikroskopie. 8: $1-14$.

1953b. Mikrosporenstratigraphie der Ostalpinen Salzberge. Verh. Geol. B.-A.: 161-175.

1953c. Alpine Salzmikropalaeontologie. Pal. Zschr. 27: 52-56.

1955a. Alpine Salzsporendiagnose. Zschr. Deu. Geol. Ges. 105: 234-236.

1955b. Uber die Sporendiagnose des deutschen Zechsteinsalzes und des alpinen Salzgebirges. Zschr. Deu. Geol. Ges. 105: 776-788.

1957. Bericht 1956 aus dem Laboratorium für Palynologie. Verh. Geol. B.-A.: 107-108.

1959. Sporenfunde in der karnischen, Stufe der alpinen Trias. Verh. Geol. B.-A.: 160-163.

1960. Sporen der karnischen Stufe der ostalpinen Trias. Jb. Geol. B.-A., Sonderb. 5: 107-183.

1963. Sporen aus dem südalpinen Perm. Jb. Geol. B.-A. 106: 229-363.

Kosanke, R. M. 1950. Pennsylvanian spores of Illinois and their use in correlation. Illinois State Geol. Surv. Bull. 74.

Kovalenko, L. A. 1956. Spores and pollen (in Russian) Vopr. Geol. Kuzbassa 1: $183-187$.

Kremp, G. O. W. and W. Spackman. 1962. Catalog of fossil spores and pollen 9 (Triassic-Jurassic), 13 (Carboniferous-Permian). Coll. Min. Industr., Penns. State Univ., Pennsylvania.

KRUTzsch, W. 1954. Möglichkeiten zur Benennung und Bezeichnung von fossilen Sporen und Pollen. Geologie 3: 67-76.

Taugourdeau-Lantz, J. 1962. Contribution à la connaissance de la microflore du Trias (abstract only). Pollen et Spores 4: 360.

Leschix, G. 1955. Die Keuperflora von Neuewelt bei Basel. Schw. Pal. Abh. 72: $1-70$.

1956. Sporen aus dem Salzton des Zechsteins von Neuhof bei Fulda. Palaeontographica B, 100: 122-142.

1959. Sporen aus den Karru-Sandsteinen von Noronaub (S.W. Afrika). Senck. Leth. 40: 51-59.

LUBER, A. A. 1938. Spores and pollen of Permian coaly sediments from SSSR (in Russian, with English summary). Probl. Sovj. Geol. 8: 152-160. 1955. Atlas of spores and pollen from Paleozoic deposits in Kazakhstan (in Russian; translations in English and French available). Ak. Nauk kazakh. SSSR, Alma-Ata.

LuECK, H. 1913. Beitrag zur Kenntnis des älteren Salzgebirges im BerlepschBergwerk bei Stassfurt nebst Bemerkungen über die Pollenführung des Salztones. Thesis. Leipzig.

Maljavkina, V. S. 1953. Spores and pollen from the Upper Triassic and the Lower and Middle Jurassic in the Uraldistrict (in Russian) Trudy V.N.I.G.R.I., n.s. 75: 93-147. Paleobot. sbornik, Leningrad, Moscow.

Manum, S. 1960. On the genus Pityosporites Seward 1914. With a new description of Pityosporites antarcticus Seward. Nytt Mag. Botanik 8: 11-15.

Markova, L. G. 1962. Spore- and pollen-complexes of Mesozoic deposits of the West-Siberian Lowland (abstract only). Pollen et spores 4: 362-363.

NiLsson, T. 1958. Über das Vorkommen eines mesozoischen Sapropelgesteins in Schonen. Lunds Univ. Arsskrift, n.s. Avd. 2. 54, no. 10: 1-112.

PANT, D. D. 1954. Suggestions for the classification and nomenclature of fossil spores and pollen grains. Bot. Rev, 20: 33-60. 
PANT, D. D. 1955. On two new bisaccate spores from the Bacchus Marsh tillite, Victoria (Australia). Ann. Mag. Nat. Hist. 8: 757-764.

Pautsch, M. E. 1958. Keuper sporomorphs from Swierczyna, Poland. Micropaleontology 4: 321-325.

Potonik, R. 1953. Zur Palaeontologie der Sporites. Pal. Zschr. 27: 32-36. 1954. Stellung der palaeozoischen Sporengattungen im natürlichen System. Pal. Zschr. 28: 103-139.

1956. Synopis der Gattungen der Sporae dispersae, Teil I. Beih. Geol. Jb. 23. 103 pp.

1958. Synopis der Gattungen der Sporae dispersae. Teil II. Beih. Geol. Jb. 31. 114 pp.

1960. Synopis der Gattungen der Sporae dispersae, Teil III. Beih. Geol. Jb. 39. 189 pp.

and W. KIAus. 1954. Einige Sporengattungen des alpinen Salzgebirges. Geol. Jb. 68: 517-546.

and G. KREMP. 1954. Die Gattungen der palaeozoischen Sporae dispersae und ihre Stratigraphie. Geol. Jb. 69: 111-194.

and 1 1955. Die Sporae dispersae des Ruhrkarbons, ihre Morphographie und Stratigraphie, mit Ausblicken auf Arten anderer Gebiete und Zeitabschnitte, Teil I. Palaeontographica B, 98: 1-136. and 1 1956. Idem. Teil II. Palaeontographica B, 99: 85-191. and 1956 . Idem. Teil III. Palacontographica B, 100: 65-121.

Remy, W. 1954. Die Systematik der Pteridospermen unter Berücksichtigung ihrer Pollen. Geologie 3: 312-323.

1954. Monosaccate Pteridospermenpollen aus den Karbon und Perm. Pal. Zschr. 28: 140-144.

RomanovskajA, G. M. 1962: Triassic, Lower and Middle Jurassic spore- and pollen-complexes of W-Kazakhstan (abstract only). Pollen et Spores 4: 373-374.

Samorlovich, S. R. 1953, 1961. Spores and pollen from Permian deposits of the Cherdyn and Aktyubinsk areas, Cis-Urals. Translation of the Russian text (1953) in Oklahoma Geol. Surv. Circ. 56.

SchaArschmidT, F. 1963. Sporen und Hystrichosphaerideen aus dem Zechstein von Büdingen in der Wetterau. Palaeontographica B, 113: 38-91.

Schemel, M. C. 1951. Small spores of the Mystic Coals of Iowa. Am. Midl. Naturalist 46: 743-750.

Schopf, J. M. 1938. Spores from the Herrin (no. 6) Coal Bed in Illinois. Illinois State Geol. Surv., Rep. Invest. 50.

- et al. 1944. An annotated synopis of Paleozoic fossil spores and the definition of generic groups. Illinois State Geol. Surv., Rep. Invest. 91.

SEWARD, A. C. 1914. Antarctic fossil plants. Nat. Hist. Rep. Brit. Ant. Exp. 1910, Geol. 1. 49 pp. London.

SrTtler, C. 1955. Méthodes et techniques physico-chimiques de préparation des sédiments en vue de leur analyse pollinique. Rev. Inst. Pétrole 10: 103-114.

Stapin, F. L. et al. 1960. Palynological techniques for sediments. Micropaleontology 6: 329-331.

STUHL, A. 1962. Results of spore investigations of Permian sediments of the Balaton Upland (in Hungarian, with German summary). Bull. Hung. Geol. Soc. 91: 405-412.

Thiergart, F. und U. Frantz. 1962. Pollen und Sporen einer Kohlenprobe von Kothagudem, Indien. Ber. Deu. Bot. Ges. 75: 71-77.

Townrow, J. A. - 1962. On some disaccate pollen grains of Permian to Middle Jurassic age. Grana Palynologica 3: 13-44.

VIRkKI, Chinna. 1938. On the occurrence of winged spores in the Lower Gondwana rocks of India and Australia. Proc. Indian Ac. Sci. B. 6: 428-431. 1946. Spores from the Lower Gondwanas of India and Australia. Proc. Nat. Ac. Sci. India 15: 93-176.

Williams, R. W. 1955. Pityosporites westphalensis n. sp.: an abietineous type pollen from the Coal Measure of Britain. Ann. Mag. Nat. Hist. 8, ser. 12, no. $90-$ LVII: $465-473$. 
WiLson, L. R. 1962. Plant microfossils from the Flowerpot formation Greer County, Oklahoma. Okl. Geol. Surv. Circ. 49. and B. S. VenKatachala. 1963. A morphologic study and emendation of Vesicaspora Schemel 1951. Okl. Geol. Notes 23: 142-149.

Zoritscheva, A. I. and M. A. Sedova. 1954. Spore-pollen complexes from Upper Permian deposits from some localities in North European Russia (in Russian). Rep. Geol. Res. Inst. VSEGEI. Moscow. 